\title{
The Influence of Electroosmosis on Compressibility of Tanon's Clay
}

\author{
Niken Silmi Surjandari a,*, Yusep Muslih Purwana ${ }^{a}$, Rizky Agung Wijaya ${ }^{\text {a }}$ \\ ${ }^{a}$ Civil Engineering Department, Faculty of Engineering, Sebelas Maret University, Jl. Ir. Sutami 36A, Surakarta, 57126, Indonesia \\ Corresponding author: *nikensilmisurjandari@staff.uns.ac.id
}

\begin{abstract}
Clay soils have a tendency to have high water content, high plasticity, long decline time, low permeability, and low bearing capacity. This study aims to determine the effect of electro-osmosis on clay soil compressibility. This research employed clay taken from Tanon, Sragen, Central Java. Electro-osmosis testing is carried out by physical model experiments using variations in the distance between the electrodes, which are $30 \mathrm{~cm}$ and $45 \mathrm{~cm}$, as well as variations in the potential difference of 0 ; 4,5 ; 9 ; 12 volts. The physical model of box-shaped electro-osmosis is $50 \times 30 \times 15 \mathrm{~cm}$. The test results show that electro-osmosis can reduce the compressibility of clay soil. This can be seen in the compressibility index (Cc) value of the soil, which experienced the greatest decrease reaching $60 \%$ compared to the land that was not electroosmosed. The greater the value of soil water content, the greater the compressibility of the soil. Soil strain is reduced by $35 \%$ compared to unelectroosmotic soil. The modulus of elasticity (Eedo) of the soil increased by $137 \%$. The most water volume that comes out is $94 \mathrm{ml}$ at a voltage of 12 volts and a distance of $30 \mathrm{~cm}$. The process of electro-osmosis is influenced by the distance and potential differences that are given. However, the most influential factor is the distance between the electrodes. This research proves that the electro-osmosis process can reduce the compressibility of clay soil.
\end{abstract}

Keywords—Clay soil; electro-osmosis; soil compressibility.

\section{INTRODUCTION}

The growth of the high population in Indonesia drives the demand for infrastructure to be increased. Not all of the land can be used directly to construct buildings. Some types of soil would have adverse characteristics if a building was built on it. Before construction begins, the soil should be stabilized to increase the soil's strength and reduce the possibility of settlement. There are many types of soil improvement in civil engineering, and it depends on the needs in the field.

Java island is dominated by clay which has a tendency to have problems with the climate in Indonesia. During the rainy season, the ground will lose its strength, and during the dry season, the ground will break and make buildings damaged. Clay soils with high water content are more dangerous and have a unique treatment to prevent building damage. Most clay soils with high moisture content have low-end strength, are easily deformed, have low permeability, and high compressibility [1]-[4].

Soil improvement in a broad sense shows a procedure/method used to change one or several soil properties to increase its engineering properties. The primary purpose of soil improvement is to increase the soil's strength [5], [6]. The drainage method is used to increase soil strength by reducing the pore water on the soil by the various types of soil improvement methods. The soil will be conducted by an electrical current that attracts the water and transporting it from the positive electrode to the negative electrode. Soil strength depends on the effective stress and the tension between the grains of the soil. This appears to be a sentence fragment. Consider rewriting it as a complete sentence. Hence, the reduction in pore water stress will be increasing the effective stress and soil strength [1], [3]-[10].

Consolidation is a process of discharging pore water in low permeability soil due to the increase in loading. During the loading increment, pore pressure increases, pore water is expelling, and soil volume decreases. The volume change which occurs during consolidation takes place only in the voids. The pore volume initially filled by air and water becomes smaller due to the applied stress makes the soil becomes denser. The value of the change in soil volume at inevitable stress can represent the soil's stiffness. The smaller the value of the changes that occur, the more rigid the soil, and the greater the value of soil volume changes, the softer the soil [11]-[14].

Every material must have a shrinkage due to the pressure received. Likewise, the soil has compressibility, especially in clay soils with high water content. Soil compressibility is the 
ability of the soil to change in volume due to the pressure above it. parameters that affect the compressibility of the soil are [15]:

- compression coefficient $\left(a_{\mathrm{v}}\right)$

- volume change coefficient $\left(\mathrm{m}_{\mathrm{v}}\right)$

- compression index $\left(\mathrm{C}_{\mathrm{C}}\right)$

Further, compressibility represents the amount of settlement of the area that would happen or take place. Soft soils, such as alluvial silt and clays, are too weak to carry any but lightest foundation loads unless the shear strength is first increased by consolidation [3], [16]. Therefore, this study was made to determine the influence of electro-osmosis on clay's compressibility, especially in Tanon, Sragen, Central Java.

\section{MATERIALS AND METHOD}

\section{A. Clay}

The clay was brought from Desa Jono, Sub District of Tanon, Sragen, Central Java. The disturbed soil from Desa Jono was taken to the laboratory by cleaning the topsoil and take it about $0.5-1 \mathrm{~m}$ depth. Laboratory testing might be applied to know the soil properties and the result of soil testing shown in Table 1.

TABLE I

INDEX PROPERTIES OF TANON's SOIL

\begin{tabular}{clcc}
\hline No. & Soil Testing & Unit & Result \\
\hline 1 & Water content & $\%$ & 43.80 \\
2 & Bulk density & $\mathrm{gr} / \mathrm{cm}^{3}$ & 1.77 \\
3 & Specific Gravity & - & 2.61 \\
& Grain-size Analysis & & \\
& a. Gravel & $\%$ & 0.02 \\
4 & b. Sand & $\%$ & 6.98 \\
& c. Silt & $\%$ & 39.45 \\
& d. Clay & $\%$ & 53.55 \\
& Atterberg Limit & & \\
\multirow{2}{*}{5} & a. Liquid Limit (LL) & $\%$ & 83.76 \\
& b. Plastic Limit (PL) & $\%$ & 33.85 \\
& c. Plasticity Index & $\%$ & 49.91 \\
& (PI) & & Clay of high plasticity \\
\hline
\end{tabular}

\section{B. Electoosmosis}

Electroosmosis is a simple method of drainage. This method was conducted in the laboratory by using a box with dimensions of $50 \mathrm{~cm} \times 30 \mathrm{~cm} \times 15 \mathrm{~cm}$. Copper plates with a diameter of $1 \mathrm{~mm}$ holes and $1 \mathrm{~cm}$ distance each hole were acted as anode and cathode. The anode and the cathode were installed in two variations of distance. At first, anode and cathode would be installed in $30 \mathrm{~cm}$ and then installed in 45 $\mathrm{cm}$. The function of this plate is to transport the electric current to the soil.

The sample taken from the field was dried up and filtered with sieve no.4 (4,75 mm). Mixing the sample with water until the soil saturated. Put the sample on the box and flatten it. Plastic wrap was placed on the top of the box to prevent evaporation during the electro-osmosis process. The electric currents were used in this study were divided into four variations that were $0,4.5,9$, and 12 volts. The electrical currents were applied throughout electrodes to pass through the soil, and the liquid move from the anode to the cathode. The experiment lasted for 72 hours, and the water was collected into the glass. The volume of water was measured every 24 hours. The schematic configuration of the electroosmosis test is shown in Figure1.

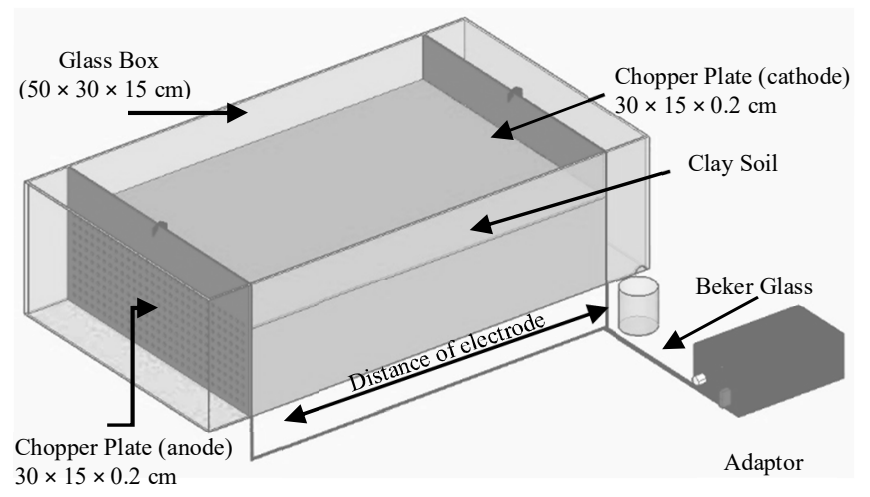

Fig. 1 Schematic configuration of the electro-osmosis test

When an electric current is conducted to the soil, there are electrolysis proses during the electro-osmosis. Electrolysis is a process of splitting up water molecules [17],[21],[22]. The process of electrolysis is shown as the following equation (1) and (2).

Cathode $\quad:: 2 \mathrm{H}_{2} \mathrm{O}+2 e^{-} \rightarrow 2(\mathrm{OH})^{-}+\mathrm{H}_{2} \uparrow$

Equation (1) and (2) shows that the electro-osmosis process produces oxygen and hydrogen. This phenomenon of releasing oxygen and hydrogen could be changing the degree of acidity of the soil.

\section{Consolidation modification}

The method of consolidation in this study was referred to ASTM D2435 with a modification. The modification means consolidation test was tested without using water because the sample was assumption as saturated soil and to kept the water content the same as the condition after the electro-osmosis process. The sample was loaded axially with stress increments. Each stress increments was applied by doubling the pressure to obtain values approximately $50,100,200$, and $400 \mathrm{kN} / \mathrm{m}^{2}$. The plasticine shall be applied to prevent change in specimen's water content due to evaporation. The mass of the specimens should be measured before each pressure increment is applied.

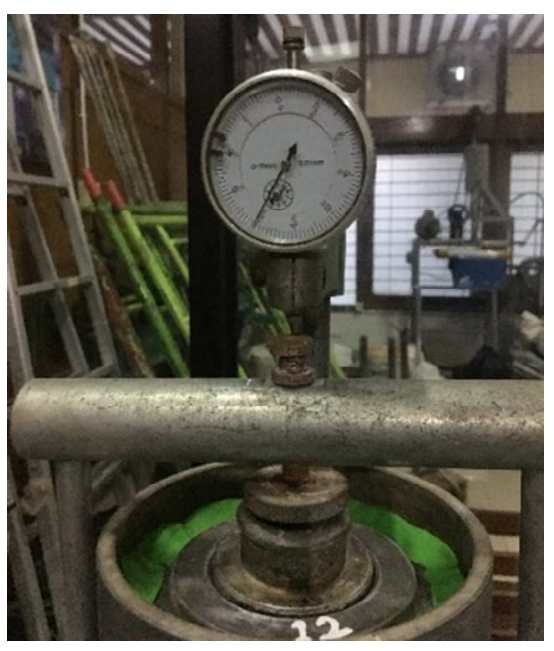

Fig. 2 Modified consolidation test 
The compression index $\left(\mathrm{C}_{\mathrm{c}}\right)$ is equal to the field consolidation curve slope plotted to the logarithmic scale of pressure in the linear range.

$$
C_{c}=\frac{\Delta e}{\Delta \log p}=\left(\frac{e_{1}-e_{2}}{\log \frac{p_{2}}{p_{1}}}\right)
$$

The coefficient of volume compressibility $\left(\mathrm{m}_{\mathrm{v}}\right)$ is the change in volume per unit volume for each unit of change in stress and this value can reflect the soil's consistency.

$$
m_{v}=\frac{a_{v}}{1+e_{1}}=\frac{1}{1+e_{1}}\left(-\frac{\Delta e}{\Delta p}\right)
$$

The oedometric modulus ( $\left.\mathrm{E}_{\mathrm{oedo}}\right)$ is the ratio between strain and stress of the material and the value was representing soil consistency or stiffness.

$$
E_{\text {oed }}=\frac{\Delta \sigma \prime}{\Delta \varepsilon}=\frac{1}{m_{v}}
$$

\section{RESULT AND DISCUSSION}

\section{A. The Effect of Electroosmosis on Total Water Output}

At the electro-osmosis processing stage, the volume of water output was measured every 24 hours. After being conducted with an electric current in 72 hours, the total water output was calculated. The recapitulation of total water output is shown in Fig 3.

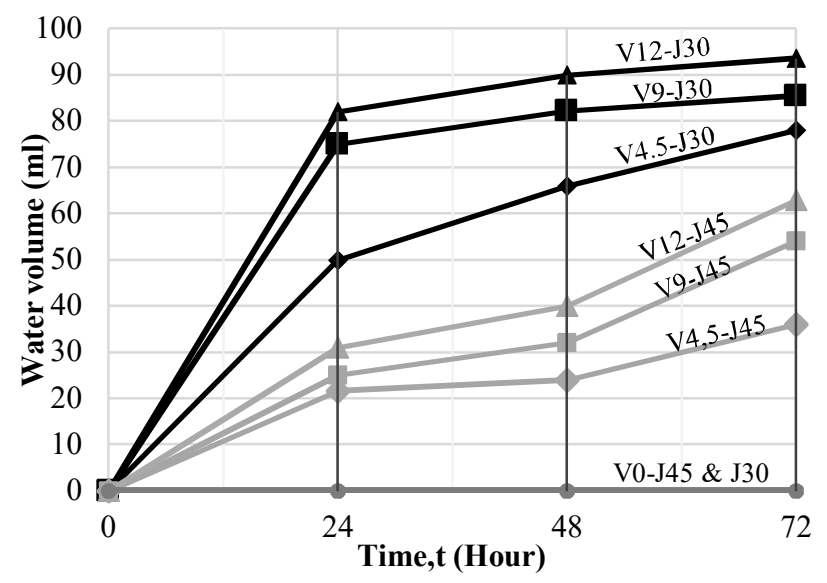

Fig. 3 The water volume flow

Figure 3 shows the total water output between the group with electro-osmosis in $30 \mathrm{~cm}$ and $45 \mathrm{~cm}$ electrode distance. The soil without electro-osmosis remains unchanged after 72 hours. The soil with electro-osmosis keeps growing, total water output is related to the amount of electrical current. Fig 2 shows that the total water output value increased along with increasing electric current [17], [28]. On the other hand, the electrodes' distance affects the total water output during the electro-osmosis process. The electro-osmosis with a $45 \mathrm{~cm}$ electrode distance showed the total water discharge is lower than the electro-osmosis with a $30 \mathrm{~cm}$ electrode distance.

The sample with a $30 \mathrm{~cm}$ distance of electrode released the higher volume of water output in 24 hours, and the volume water output getting decreased in the following 24 hours. In the 48 hours, the total water output grows up with insignificant value and going up in 72 hours. The distance between the electrodes affected the time electron transported the water to the cathode. The other factor affecting the electroosmosis process is the distance between the electrode. The total water output increased along to the shortest distance of the electrode.

It was known that the most affecting factor in the electroosmosis process is the distance of the electrode. As shown in Figure 3, the sample with the shortest distance of the electrode and the lowest current was released more water volume than the sample with the longest distance of electrode and highest current.

\section{B. The Effect of Electroosmosis on Soil Deformation}

Soil samples that were treated using electro-osmosis process, trimmed into consolidation specimens, and being tested. At the consolidation testing process, the change in the height of the sample was recorded at the intervals $0,0.25,0.5$, $1,2,4,8,15,30,60,120,240,480$, and 1440 minutes. The data plotted on the curve of time-deformation is shown in Figure4.
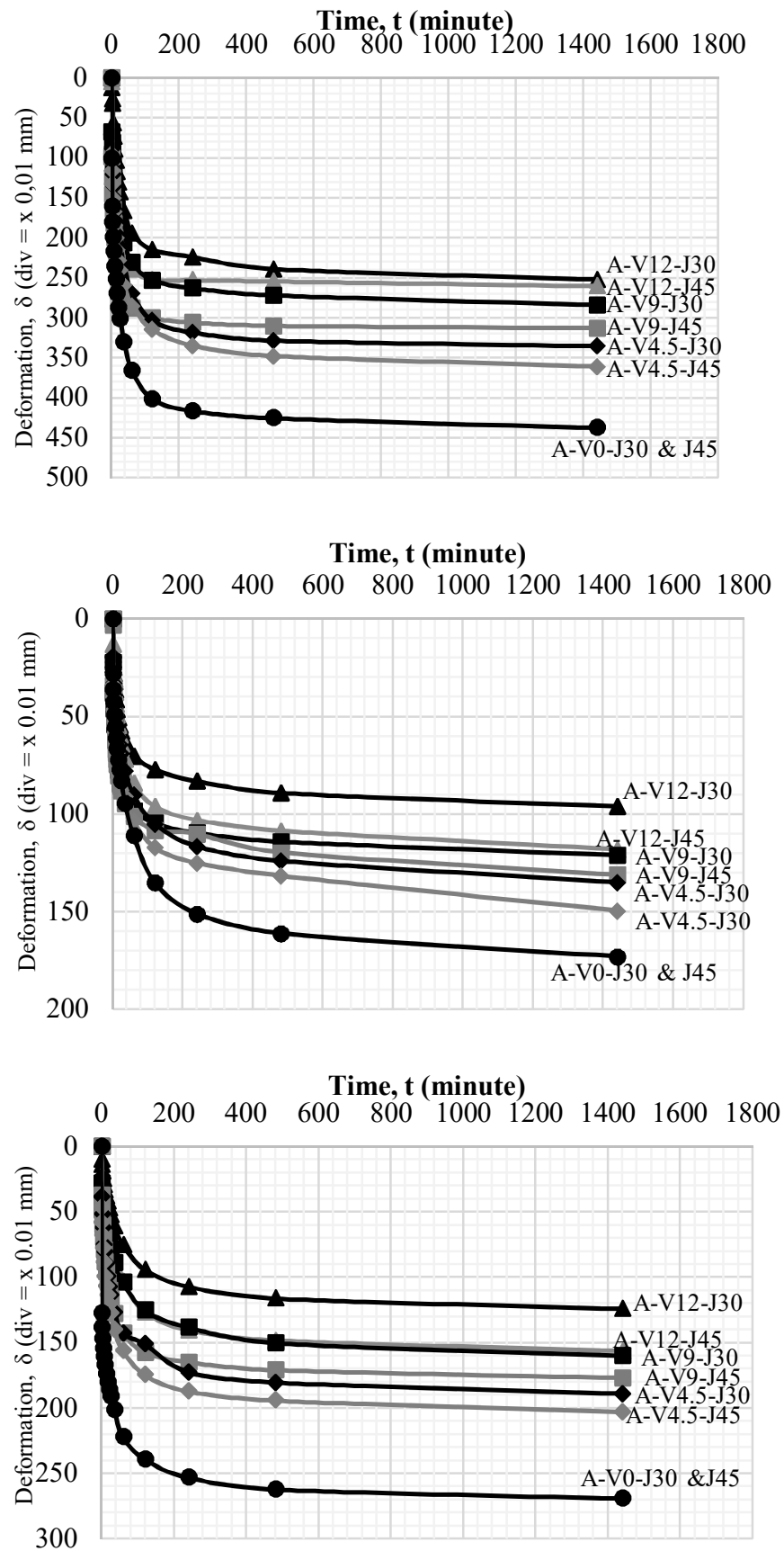


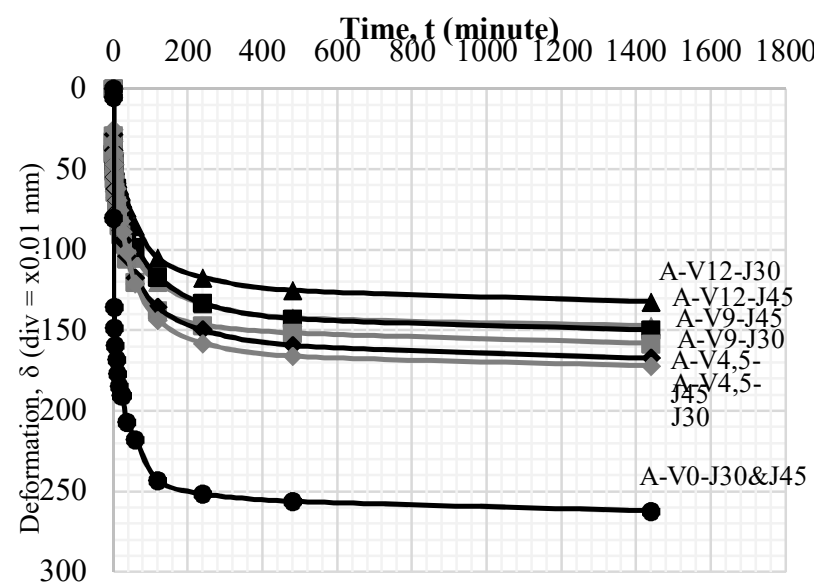

Fig. 4 The effect of electro-osmosis on the deformation of Soil at Various pressure : (a). $50 \mathrm{kN} / \mathrm{m}^{2}$, (b). $100 \mathrm{kN} / \mathrm{m}^{2}$, (c). $200 \mathrm{kN} / \mathrm{m}^{2}$ and (4). $400 \mathrm{kN} / \mathrm{m}^{2}$

At the consolidation testing, the samples were given axial pressure and being changed in the height of the sample. From Figure4, the deformation occurred in intervals 0 until 480 minutes, and deformation activities were reduced or insignificant value on the following time. The soil without the electro-osmosis process being high deformed than the sample with electro-osmosis. At the first pressure, the total deformation of all samples is greater than the other pressure. The following pressure, the soil deformation remains decreased, but the value was not greater than before.

At various pressure, it is observed that the electro-osmosis process influences soil deformation. Figure 4 shows the amount of electric current is decreasing the deformation of soil. On the other hand, the electrode distance also affects the deformation value. The closer electrode distance will reduce the deformation of the soil [14], [18], [23].

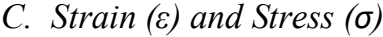

In the consolidation testing process, the amount of strain is used as one of the observed parameters. The value of strain was calculated by dividing the change in the samples' height with the samples' initial height, and the value is multiplying by 100 percent. The result of the calculation for the strain of samples is presented in Figure5.

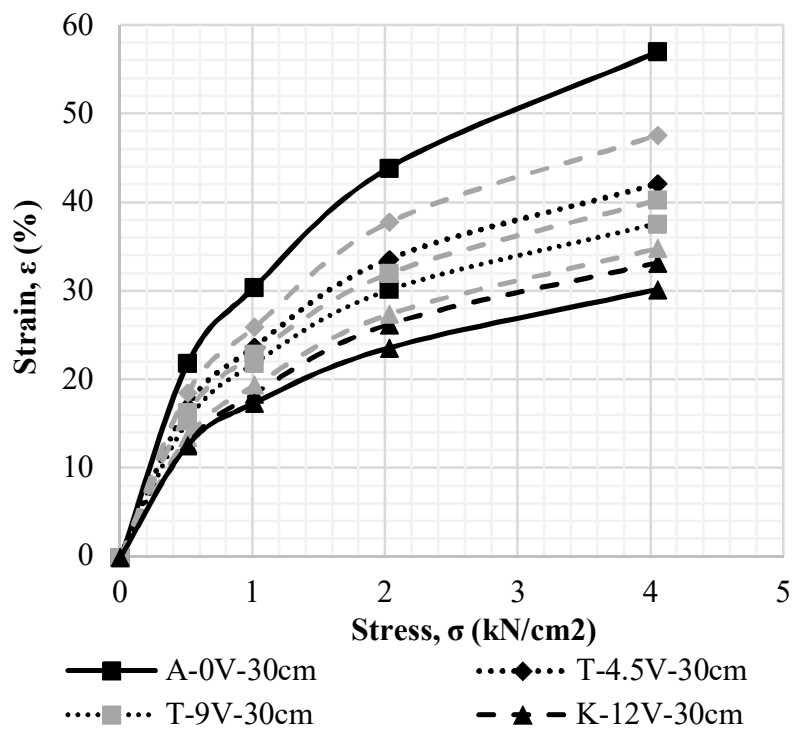

Fig. 5 Soil Strain during consolidation test
As shown in Figure 5, the soil without electro-osmosis gets increased during the increment of pressure. At the second pressure, the strain of the soils is not greater than before. The strain of soil remains increased during the increment of pressure. Conversely, the result shows that the strain of soils decreased at a higher amount of electric current. The lower strain of soil, the consistency of soil is stiffer [14], [18], [20], [23], [26].

The results indicate that a decrease in the strain of the sample with the electro-osmosis process. The result also shows that the various electric current and various distances affect the strain of soil. Moreover, the shortest distances of the electrode resulted in a lower strain of soil. Consequently, the electrode's longest distance would be needed a long time for the current to transfer.

\section{Oedometric Modulus ( $\left.E_{\text {oedo }}\right)$}

One of the parameters obtained from the consolidation test is the modulus of soil elasticity. The modulus of elasticity is a value used to determine how much the soil experiences a strain at specific stress. The number of modulus of elasticity was calculated by dividing the stress with the change of strain. The result of the calculation for modulus of elasticity is presented in Figure 6.

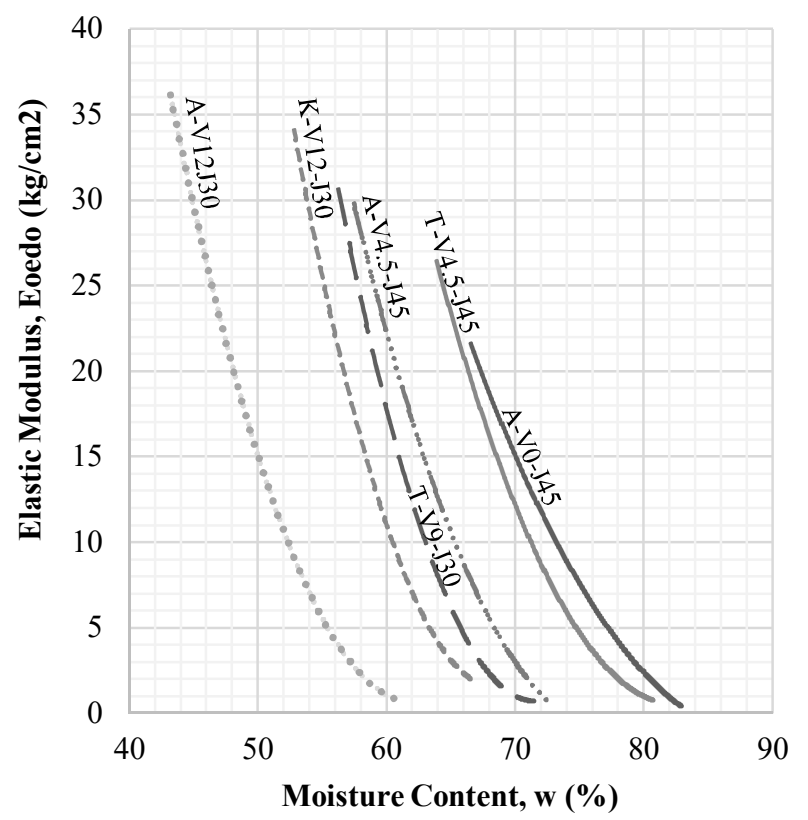

Fig. 6 The change of elastic modulus

At the consolidation testing stage, the samples' water content was released during the increment of pressure. The void between the soil that is filled with water being compressed by axial pressure. The water that was released would be evaporated, and the samples' mass was measured before increment pressure. The mass of samples calculated to get water content during increment pressure. The amount of change of sample height calculated as restrain and the pressure from the consolidation test calculated by dividing it by the disk area.

Figure 6 shows that soil without electro-osmosis has the lowest modulus elasticity and higher moisture content until the testing was done. Commonly, the curves of change in modulus elasticity were formed parabolic curves. At the 
second pressure, the modulus elasticity was increased but relatively insignificant. The electro-osmosis affected the water content of the soil become decreased. The greater the moisture content, the more the modulus elasticity was decreased, and the lowest moisture content, the modulus elasticity was increased [14], [18], [20], [27].

However, the modulus elasticity was increased significantly. From the result, it can be resumed that the electro-osmosis process increased the modulus elasticity. Increasing the amount of electric current in consequence of modulus elasticity increased. The longer distance of the electrode also postponed transporting electric current from the anode to the cathode. Moreover, the increased distance of the electrode resulted in the value of modulus elasticity were decrease.

\section{E. Void Ratio}

The void ratio is affected by many interrelated factors such as the weight of solid, specific gravity of soil, soil volume, and pore volume. The void ratio resulted in dividing the volume of the pore with a volume of solid. The result of the calculation is shown in Figure 7.

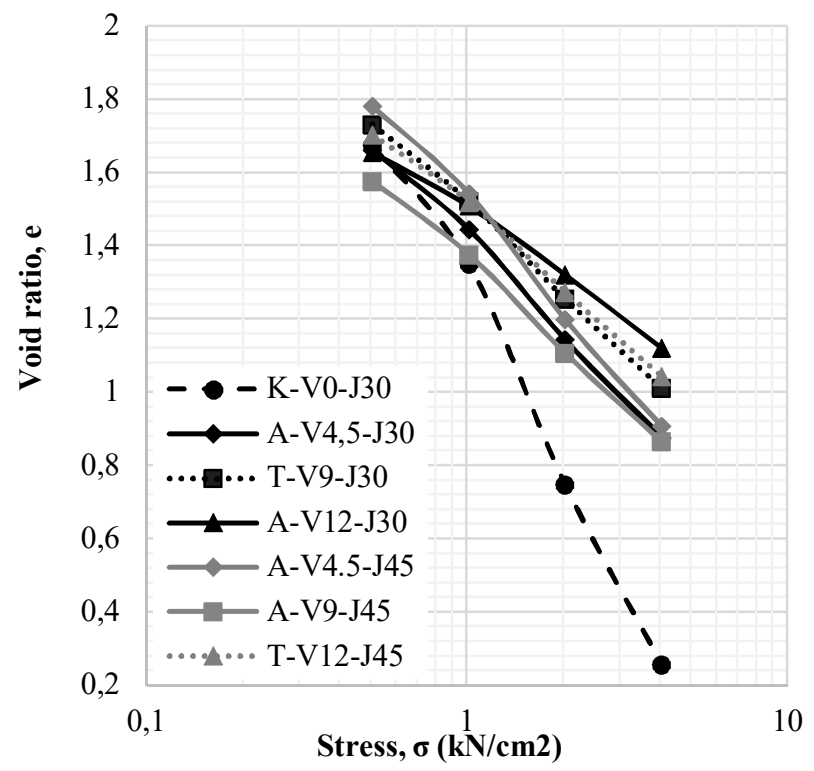

Fig. 7 The change of void ratio with the pressure during consolidation test in various electric current and electrode distances.

Figure 7 shows the change in void ratio during the consolidation testing. The change of void ratio is influenced by the volume of pore water and the volume of solid. The difference in the initial void ratio $\left(\mathrm{e}_{0}\right)$ is caused by consolidation during the electro-osmosis stage. The consolidation happened when the water was released during the electro-osmosis. The void of the pore is filled with air and being compressed by the mass of the overburden. Therefore, during the electro-osmosis process, there is a consolidation process, but the magnitude of consolidation is minimal.

The sample without electro-osmosis had the largest compression shown on the curve. The amount of compression can be seen based on the magnitude of the change in the soil's pore ratio. The samples without electro-osmosis have a large change in pore ratio compared to samples without electroosmosis. The curve between void ratio and stress formed a gradient. It means that the greater the slope of the line, the greater the compressibility will occur. The curve's gradient is influenced by the amount of electric current that flowed and the electrodes' distance. The compression of the soil could increase if the amount of the electric current decreased. The other factor that is affecting the compression of the soil is the distance of the electrode. The compression of soil would be decreased when the distance of the electrode being shorter [14].

\section{F. Coefficient of volume compression $\left(m_{v}\right)$}

The coefficient of volume compression $\left(\mathrm{m}_{\mathrm{v}}\right)$ or sometimes called the modulus of volume change, is one of the parameters which indicates the compressibility per unit thickness. The value of the coefficient of volume compression $\left(\mathrm{m}_{\mathrm{v}}\right)$ is also represented as clay type. The value of the coefficient of volume compression $\left(\mathrm{m}_{\mathrm{v}}\right)$ calculated for the void ratio on each load increment of the consolidation test. The result of the calculation for the coefficient of volume compression $\left(\mathrm{m}_{\mathrm{v}}\right)$ shown in Figure 8.

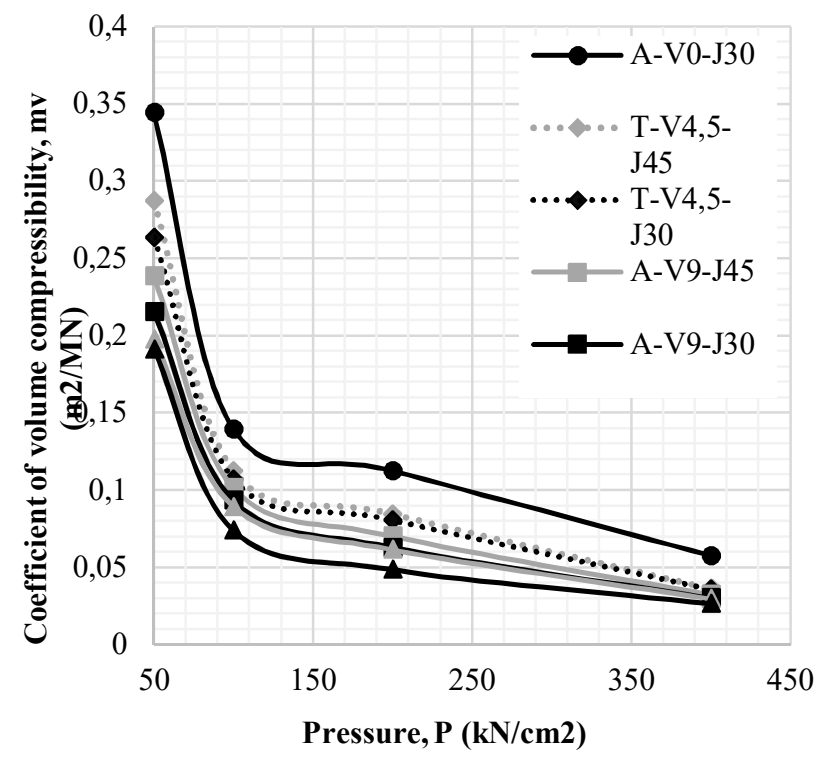

Fig. 8 The change of coefficient volume compression $\left(\mathrm{m}_{\mathrm{v}}\right)$

Figure 8 shows the change in coefficient volume compression during the electro-osmosis process. The samples without the electro-osmosis process have a greater value of coefficient volume compression than the sample with the electro-osmosis process. At the first pressure, all of the various electric current and the electrode's distance had the highest value of $m_{v}$. The value of $m_{v}$ being insignificant after the second increment pressure and following pressure. The greater the coefficient volume compression, the greater the compression that occurs. Conversely, the smaller the volume compression coefficient value, the smaller the compression that occurs. From the result, it can be resumed that the coefficient of volume compression decrease as the amount of electric current increased. The shortest distance of the electrode is decreasing the value of the coefficient of volume compression.

\section{G. Compression Index $\left(C_{c}\right)$}

Compression index $\left(\mathrm{C}_{\mathrm{c}}\right)$ is one of the parameters derived from consolidation tests to indicate the compressibility of soils, from which an estimate of the amount of settlement 
would happen. The result of the calculation for the compression index $\left(\mathrm{C}_{\mathrm{c}}\right)$ is shown in Figure 9.

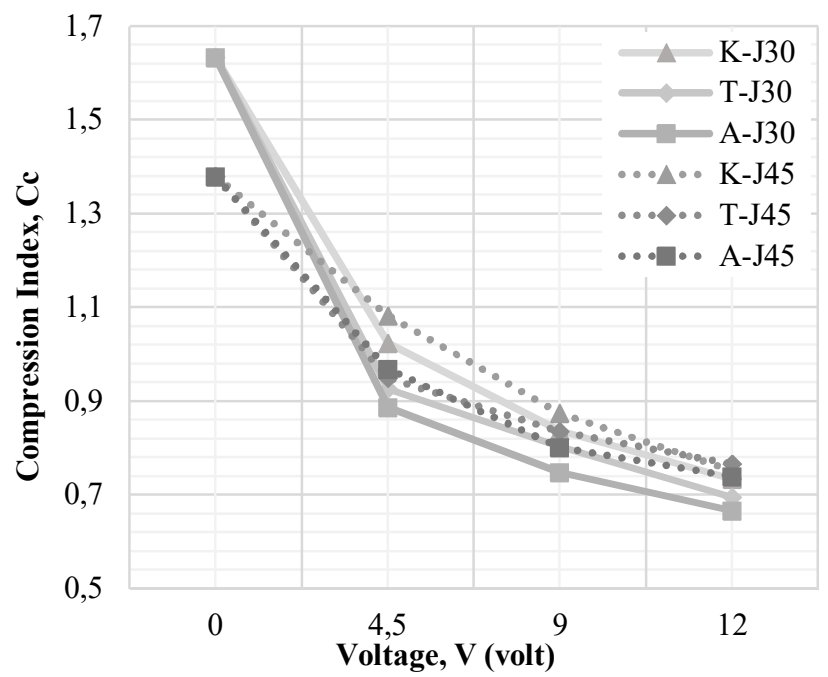

Fig. 9 Index of compressibility in a various amount of electric current and distance

The compression index $(\mathrm{Cc})$ value is equal to the gradient of the field consolidation curved plotted to a logarithmic scale of pressure in the linear range. The result reveals that the variation in the electric current and distance of the electrode was affected by the compression index $\left(\mathrm{C}_{\mathrm{c}}\right)$. A higher amount of electric current would be decreasing the compression index. The other factor that influences the compression index is the distance of the electrode. The shortest distance of the electrode would be decreasing the compression index. The dominant factor that affected the value of the compression index is the distance of the electrode [1], [27].

\section{H. Acidity degree of soil $(\mathrm{pH})$}

During the electro-osmosis process, there is another reaction that occurs at that stage. This phenomenon is called electrolysis which is broke up the hydrogen bond in the water molecule. Releasing the hydrogen and oxygen particle would increase the value of the acidity degree of soil in the area of the anode, and the acidity degree of soil in the area of the cathode decreased [17], [19], [21], [22]. The result of the experiment is shown in Figure 10.

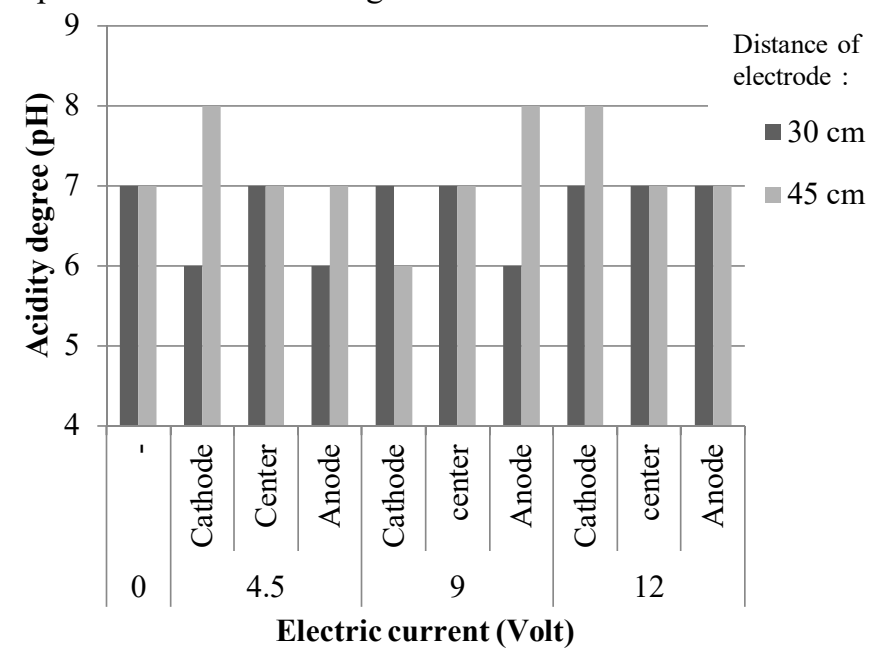

Fig. 10 Acidity degree $(\mathrm{pH})$ of soil in a various amount of electric current and distance of the electrode
The result from the experiment shown that the electroosmosis process changed the acidity degree of the soil. The soil near the anode tends to decrease in acidity degree $(\mathrm{pH})$ of soil. In contrast with the soil near the cathode, the acidity degree $(\mathrm{pH})$ tends to increase. Based on the results of the analysis in Figure 10, it was found that the dominant factor affecting the change of acidity degree $(\mathrm{pH})$ is the amount of the electric current. The value of acidity degree changed along with increasing the amount of electric current.

\section{The Moisture Content of soil (w)}

The soil with high moisture content was treated by using electro-osmosis. Its process was drained the moisture content of soil and stabilizing it from the settlement. At the electroosmosis process, the moisture content was obtained by taking the soil from the box. The soil from the electro-osmosis process was divided into nine segments that were classified base on the position. So, each position has three segments. The result of moisture content testing is shown in Figure11.

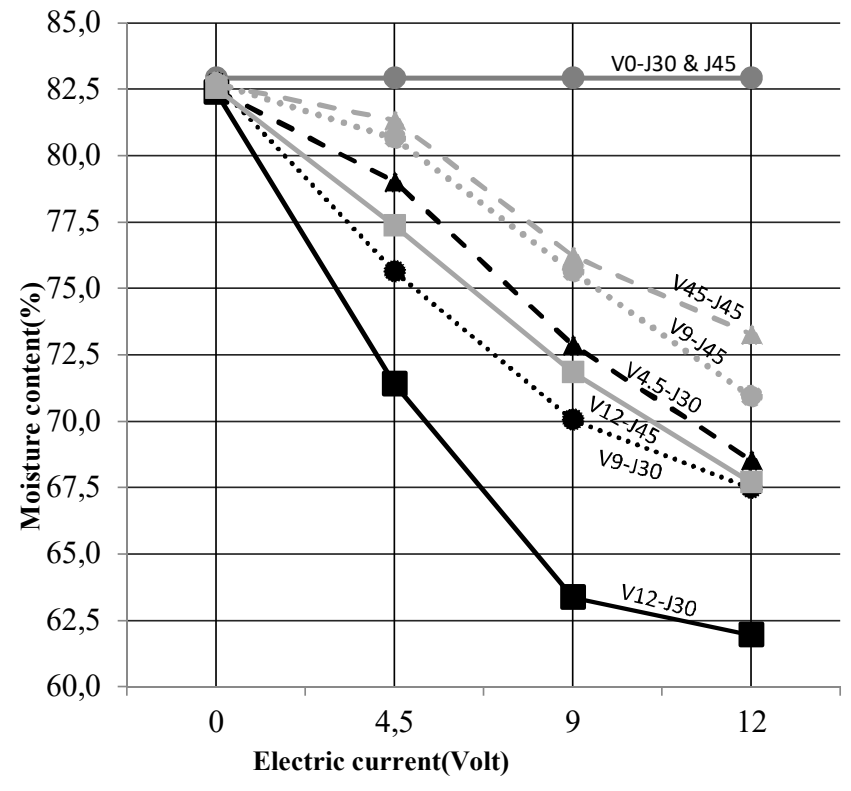

Fig. 11 The changes in moisture content with various electric current

Figure11 shows the change of moisture content at the various electric current and distance of the electrode. As shown in Figure 11, the sample's moisture content without electro-osmosis remains unchanged after 72 hours while the soil with electro-osmosis process gets decreased. The electric current flowed on the ground carrying water molecules so that the anode area tends to dry. Whereas in the cathode area, the water content tends to remain constant.

It is known that the soil with high moisture content needs long-term drainage. Clays were classified as soil with low permeability, meaning that the condition of the soil in high moisture content would need more time to release the water [1], [17], [19], [30]. At all of the variation, it is observed that the moisture content decrease as the amount of electric current increased, and the shortest distance of the electrode affected the moisture content were decreased. The dominant factor that strongly influences the change of moisture content is the distance of the electrode. The longer distance of the electrode also postponed the transporting activity of water during the electro-osmosis. 


\section{CONCLUSIONS}

From the analysis that was carried out in this research, the researchers highlighted the conclusion as follows: The amount of water volume that comes out in the electro-osmosis process is influenced by several factors, namely the distance factor and the voltage factor. The farther the distance between the electrodes, the less the volume of water that comes out. The greater the voltage is given, the greater the volume of water that comes out. The most influencing factor is the magnitude of the applied voltage. The process of electroosmosis is decreasing the deformation of the soil. The amount of electric current is decreasing the deformation of soil. On the other hand, the electrode distance also affects the deformation value. The closer electrode distance will reduce the deformation of the soil. The amount of electric current and various distances affect the strain of soil. The increasing amount of electric current resulted in the strain would be decreased. Moreover, the shortest distances of the electrode resulted in a lower strain of soil. Consequently, the electrode's longest distance would be needed a long time for the current to transfer. Increasing the amount of electric current in consequence of modulus elasticity increased. The longer distance of the electrode also postponed transporting electric current from the anode to the cathode. Moreover, the increased distance of the electrode resulted in the value of modulus elasticity were decrease. The compression of the soil could be increased if the amount of the electric current is decreased. The compression of soil would be decreased when the distance of the electrode being shorter. The coefficient of volume compression decrease as the amount of electric current increases. The shortest distance of the electrode is decreasing the value of the coefficient of volume compression.

A higher amount of electric current would be decreasing the compression index. The shortest distance of the electrode would be decreasing the compression index. The dominant factor that affected the value of the compression index is the distance of the electrode. The electro-osmosis process changed in the acidity degree of soils. The dominant factor affecting the change of acidity degree $(\mathrm{pH})$ is the amount of the electric current. The value of acidity degree changed along with increasing the amount of electric current. The amount of moisture content decreased as the amount of electric current increased, and the shortest distance of the electrode affected the moisture content. The dominant factor that strongly influences the change of moisture content is the distance of the electrode. The longer distance of the electrode also postponed the transporting activity of water during the electro-osmosis.

\section{NOMENCLATURE}

$\mathrm{C}_{\mathrm{c}} \quad$ Compression index

e Void ratio

P Pressure

$\mathrm{m}_{\mathrm{v}} \quad$ Coefficient of volume compression

$\mathrm{kN} / \mathrm{m}^{2}$

$a_{v} \quad$ Coefficient of compressibility

$\mathrm{V} \quad$ Value of electric current

$\mathrm{m}^{2} / \mathrm{MN}$

$\mathrm{m}^{2} / \mathrm{kN}$

volt

$\mathrm{J} \quad$ Distance of electrode

A The position near the anode

$\mathrm{T}$ The position at the middle of the box

$\mathrm{K}$ The position near the cathode

\section{ACKNOWLEDGMENT}

The researchers are grateful to the research team members in this research and the Soil mechanic laboratory that facilitate this research.

\section{REFERENCES}

[1] Prastiwi, H. A., Pengaruh Elektroosmosis pada Tanah Lempung Ditinjau dari Parameter Konsolidasi Tanah, Matriks Teknik Sipil, Vol. 3 No. 4, pp. 884-891,2016.

[2] Kurniawan, E. F., Pengaruh Pola pada Drainase Vertikal Satu Arah Menggunakan Kolom Pasir pada Tanah Lunak, Matriks Teknik Sipil, Vol. 4 No. 6, Pp. 710-716, 2018.

[3] Tjandra, Daniel dan Paravita Sri Wulandari. 2006. Pengaruh Elektrokinetik Terhadap Daya Dukung Pondasi Tiang di Lempung Marina. Civil Engineering Dimension, Vol. 8, No.1, 15-19, March 2006.

[4] Tjandra, Daniel and Gogot Setyo B., Pengaruh Elektrokinetik Terhadap Peningkatan Daya Dukung Tanah Lempung Lunak, Prosiding : Pertemuan Ilmiah Tahunan XIII 2009 HATTI, 5-6 Nov, 2009 .

[5] Kusuma, A. and Agus S. M., Pengaruh Lama Pemberian Arus Terhadap Pengembangan Tanah Lempung Ekspansif Metode Elektrokinetik, Buletin Teknik Sipil, Universitas Muhammadiyah Yogyakarta, 1:1 (2017), pp. 1-7.

[6] Permadi, W. dan Brian K. P. 2016. Stabilitas Tanah Lempung Ekspansif Godong - Purwodadi KM 50 Menggunakan Proses Elektrokinetik dengan Stabilisator Accu Zuur dan Kapur. Jurnal Karya Teknik Sipil, Vol. 5, No.2, Pp. 138-147, 2016.

[7] Atmaja, Y. R., Pengaruh Penggunaan Elektroosmosis terhadap parameter kuat geser tanah lempung, Matriks Teknik Sipil, vol. 1 No. 4, pp. 30- 37, Dec. 2013.

[8] Majid, A., Pengaruh Penggunaan Elektroosmosis Terhadap Tekanan Air Pori pada Tanah Lempung, Matriks Teknik Sipil, vol. 1, No.4, pp. 371-376, Dec. 2013.

[9] Prasetyo, Agus Joko, Eko H. dan Zaenal A., Pengaruh Beberapa Jenis Elektroda untuk Menentukan Perpindahan Cesium-134 di dalam Tanah Menggunakan Metode Elektrokinetik. Youngster physics journal vol. 3,No. 4, Pp. 213-220,2014.

[10] Agustina, Rustamadji, dan Eka P., Analisis Kombinasi Preloading Mekanis dan Elektrokinetik terhadap Pemampatan Tanah Lunak Pontianak. Jurnal Teknik Sipil FT Untan, Vol 2 No. 2, Pp. 1-10, 2014.

[11] Kusriyanto, N.S., Pengaruh Elektroosmosis pada Tanah Tanon Ditinjau dari Parameter Konsolidasi Tanah dengan Penambahan Abu Ampas Tebu, Matriks Teknik Sipil, Vol. 2, No.4, Pp. 513-418, 2016.

[12] Yamali, F. R., Pengaruh Kadar Air Terhdap Nilai konsolidasi di Tanah Lempung pada Lokasi yang Sama. Jurnal Ilmiah Universitas Batanghari Jambi, Vol.11 No.1, Pp. 70-75, 2011.

[13] Das, B. M., Mekanika Tanah (Prinsip - Prinsip Rekayasa Geoteknis) Jilid I, Jakarta, Indonesia : Erlangga, 1995.

[14] Nugraha, A. S. And Sutan A. H. M., Pengaruh Waktu Pembebanan Uji Konsolidasi 1 Dimensi Terhadap Nilai Oedometric Modulus Tanah Silty Clay, Jurnal Teknik Sipil, Vol 14 No. 2,Pp. 161-179, Okt 2018.

[15] Head, K. H., Manual of soil Laboratory Testing, 2nd ed, vol. 2, London, England : Pentech Press, 1982.

[16] Yamali, Fakhrul R., Pengaruh Kadar Air Terhadap Nilai Konsolidasi di Tanah Lempung pada Lokasi yang Sama, Jurnal Ilmiah Universitas Batanghari Jambi, Vol. 11 No.1, Pp. 70-75, 2011.

[17] Ming-Jie, CAO, Ding Chun-Mei and Ren Ze-dong, Experimental Study of Electro-osmotic Dewatering in Hangbag, The open Civil Engineering Journal, Vol. 9, Pp. 7-11, 2015.

[18] Munawir, As'ad, Herlin I., and Elly R. H., Pengaruh Kadar Air Terhadap Perilaku Modulus Deformasi Tanah Lempung di Kawasan Universitas Brawijaya Malang yang Dipadatkan secara Standar, Jurnal Rekayasa Sipil, Vol.2, Pp. 147-161, 2008.

[19] Estabragh, A.R., Improvement of Clay Soil by Electro-osmosis Technique, Elsevier, Applied Clay Science vol. 95, Pp. 32-36, 2014.

[20] Yuan, J. And M.A. Hicks, Large deformation elastic electro-osmosis consolidation of clays, Elsevier, Computers and Geotechnics vol. 54, Pp. 60-68, 2013.

[21] Hu, Liming, lin zhang, and hui wu, Experimental Study of the Effects of Soil pH and Ionic Species on the Electro-omostic Consolidation of Kaolin, Elsevier, Hzardous material vol. 368, Pp. 885-893, 2018. 
[22] Ahmad, Kamarudin and Khairul kassim, Influence of Electrokinetic Processing of A Tropical Soil on the pHs of The Electrolytes. Junal Kejuruteraan, Vol. 17 (1), Pp. 39-48, 2015.

[23] Jayasekera, S., Electrokinetics to modify strength characteristics of soft clayey soils: a laboratory based investigation. Electrochim. Acta, 181 (2015), pp. 39-47, 2015.

[24] Hardiyatmo, H. C., Mekanika Tanah I, Jakarta, Indonesia : Gramedia, 1992.

[25] Peck, R. B. and Terzaghi K., Mekanika Tanah dalam Praktek Rekayasa Jilid 1., Jakarta, Indonesia : Erlangga, 1996.

[26] Zhang, Heng, Guoxiang Zhou, Jing Zhongm Zhang Shen and Xianming Shi, The Effect of Nanomaterials and Electrode Configuration on Soil Consolidation by Electroosmosis : Experimental and Modeling Studies. The Royal Society of Chemistry, 2017, 7,12103.
[27] Desiani, Asriwiyanti. Kompresibilitas tanah organik. Jurnal Teknik Sipil, 2018, 14.1: 26-44.

[28] Zhang, Lei, Li-ping jing, Ning-wei Wang, Chen Fang, Yong-qiang Li, and Zhen-dong Shan. Electro-osmosis Chemical Treatment of HighSalinity Soft Marine Soil: Laboratory Test. The Open Civil Engineering Journal, 2017, 11, Pp. 109-120.

[29] Zang, J., Wang, W., Wang, Z., Zheng, L., \& Xie, X. Field Test on Electro-Osmosis in a Heavy Metal Contaminated Soil: Electrokinetic Remediation and Reinforcement of the soil. Int. J. Electrochem. Sci, 15,2020, 1230-1241.

[30] LIU, Zhi-ming; YANG, Jian-gui; LI, Qi-meng. Soil improvement by electro-osmosis with vacuum drainage in cathode. Electron J Geotech Eng, 2016, 21.15: 1-13. 